\title{
THE CONCEPT OF KARMA YOGA AND ITS RELATIONSHIP WITH SPIRITUAL INTELLIGENCE AND EMPLOYEE PERFORMANCE OF LPD IN BULELENG REGENCY
}

\author{
I Putu Agus Adnyana ${ }^{1}$, Gusti Putu Eka Kusuma ${ }^{2}$ \\ Management, STIE Satya Dharma, Indonesia ${ }^{12}$. \\ Agusadnyana773@gmail.com
}

\begin{abstract}
This study aimed to determine the concept of Karma Yoga in relationship with spiritual intelligence and employee performance of LPD in Buleleng Regency. The concept of Karma Yoga is a value of local genius that will provide guidelines for LPD employees in the form of sincerity in working as a basis for improving employee performance of LPD. The population in this study was all active LPDs in Buleleng Regency. Sampling in this study using random sampling technique. The data analysis technique used in this study was the Component based SEM, Partial Least Square (PLS) analysis method. The results showed that the concept of Karma Yoga and spiritual intelligence had a relationship with employee performance.
\end{abstract}

Keywords: Karma Yoga Concept; Spiritual Intelligence; Employee Performance.

\section{INTRODUCTION}

The increasingly competitive business environment requires financial institutions to be able to make the right strategy to be able to win the competition with other financial institutions. The Village Credit Institution (LPD) is one of the financial institutions in Bali which is unique to other microfinance institutions because its ownership from the Village Credit Institution (LPD) belongs to a customary village which automatically belongs to the local village community or is managed by the local community. to be able to advance the traditional village in the area. One aspect of the competitive challenges faced by the Village Rural Institution (LPD) in Bali is especially the Buleleng area lies in human resource management. Data in 2019 from 169 LPDs in Buleleng Regency, 25 were getting stuck. Which means the Village Credit Institution (LPD) in Buleleng district does not operate. This shows that there is no irregularity in the management of the Village Credit Institution (LPD) in Buleleng Regency. One of the factors of the causes is due to the performance of human resources in the Village Credit Institution (LPD). According to Hyz in Wibowo (2015), the use of human resources is essential because these factors are the most important assets for the successful implementation of strategic objectives that depend on the performance of employees. 
Good performance is the most important thing for any organization to achieve organizational goals. In order to get good performance, quality human resources are needed. There are psychological factors affecting employee performance, one of which is spiritual intelligence, from the research results of Lisda (2012) concluding that spiritual intelligence has a real influence on employee performance. Apart from this, in Hinduism, human efforts to achieve the perfection of life in the form of the dhita and moksa universe can be done by taking the path of applying the teachings of Catur Marga Yoga, one of which is the actualized teachings of Karma Yoga. Karma Yoga is yoga that is an effort or action (work) that is sincere, selfless, emphasizing work as a form of devotion and devotion to God (Niskama Karma). Ngurah et al. in Sugata (2018) say that the teachings of Karma Yoga are a work ethic or work culture for Hindus in an effort to realize physical and spiritual welfare and happiness. Karma Yoga accepts life's struggles and wants to succeed in those struggles. Besides that, it does not solely rely on biological life but also concerns moral and spiritual life. The novelty of this study is to include the karma yoga variable to determine the relationship to employee performance through spiritual intelligence

The specific objective of this study was to determine the concept of Karma Yoga in relation to spiritual intelligence and performance at the Village Credit Institution (LPD) in Buleleng Regency. This research is considered vital because it can provide benefits for management, especially in the human resources of the Village Credit Institution (LPD) to be able to improve employee performance so that by increasing the performance of Village Credit Institutions (LPD) employees can maintain consistency and clarity of Village Credit Institutions (LPD) to be able to compete with other microfinance institutions. In addition, there were cases of LPDs with poor performance, where dozens of customers of one of the LPDs in Buleleng Regency protested by visiting the DPRD office because the LPD was unable to return hundreds of millions of rupiah in customer funds. This condition should not continue and occur again in other LPDs in Buleleng Regency.

\section{METHODOLOGY}

This research is explanatory in the form of causality between variables. This study examines the causal relationship between the concept of Karma Yoga, Spiritual Intelligence, and the employee performance of LPDs in Buleleng district. Model development in this study attempts to predict the causality relationship between variables.

\section{Population and Sample}

This research was conducted in all active LPDs in Buleleng Regency. It was using a random sampling technique that was spread across nine districts, namely, the districts of Banjar, Sukasada, Sawan, Kubutambahan, Tejakula, Seririt, Busungbiu, Gerogak, and Buleleng.

\section{Research Variables}

Karma Marga Yoga is an effort or action (work) that is sincere, selfless, emphasizing work as a form of devotion and devotion to God (Niskama Karma). Ngurah in Sugata (2018) states that the teachings of Karma Yoga are a work ethic or work culture for Hindus in an effort to realize physical and spiritual welfare and happiness. Karma Yoga accepts life's struggles and wants to succeed in those struggles. Besides that, it does not solely rely on biological life but also concerns 
moral and spiritual life. Karma Yoga taught by Hinduism is patterned in social practice as a noble tradition of religious communities. This shows that humans are social creatures (Koentjaraningrat, 2003). Spiritual intelligence is the human ability to interpret the meaning of life and understand the value of every action that is done and the potential ability of each human being that makes a person aware and determines the meaning, value, morals, and love for greater powers and fellow living beings because they feel as part of the whole, so that humans can place themselves and live more positively with full wisdom, peace, and true happiness. Employee performance is the work achieved by someone who is adjusted to that person's role or task in an organization in a certain period of time, which is associated with a set of values or standards from the organization where the person works.

\section{Data Analysis Techniques}

The type of data needed in the analysis of this research is primary data. In this study, primary data were obtained directly from the questionnaire filled in by respondents, namely employees of the Buleleng Village Credit Institution (LPD). Information was sought in the questionnaire regarding Karma Yoga, spiritual intelligence and LPD employee performance in Buleleng Regency. The data analysis technique used to test the hypothesis of this study is Structural Equation Modeling (SEM) with the Partial Least Square (PLS) approach. The Partial Least Square (PLS) approach was chosen with the consideration that the variables used in this study are latent variables (not directly measurable) which can be measured based on the indicators (manifest variables).

\section{The Hypothesis Result test}

\section{RESULTS AND DISCUSSION}

The results of data analysis using Structural Equation Modeling (SEM) with the Partial Least Square (PLS) approach, statistical testing between variables (paths) are presented in Table 1.

Table 1.Statistical Test Results Relationship Between Variables (Path Coefficient)

\begin{tabular}{lcccccc}
\hline & & $\begin{array}{c}\text { Original } \\
\text { Sample } \\
(\mathrm{O})\end{array}$ & $\begin{array}{c}\text { Sample } \\
\text { Mean } \\
(\mathrm{M})\end{array}$ & $\begin{array}{c}\text { Standard } \\
\text { Deviation } \\
(\mathrm{STDEV})\end{array}$ & $\begin{array}{c}\text { T Statistics } \\
(\mathrm{O} / \mathrm{STDEV})\end{array}$ & $\begin{array}{c}\mathrm{P} \\
\text { Value }\end{array}$ \\
\hline $\begin{array}{l}\text { Karma Yoga Concept } \\
\text { Intelligence }\end{array}$ & $>$ Spiritual & 0.683 & 0.761 & 0.068 & 9.154 & 0.000 \\
$\begin{array}{l}\text { Karma Yoga Concept } \\
\begin{array}{l}\text { Performance } \\
\text { Spiritual Intelligence }>\end{array}\end{array}$ & Employee & 0.765 & 0.794 & 0.145 & 7.564 & 0.000 \\
Performance & Employee & 0.784 & 0.627 & 0.176 & 6.831 & 0.000 \\
\hline
\end{tabular}

Based on the path coefficient results above, the relationship between the concept of Karma Yoga and Spiritual Intelligence and employee performance has a positive and significant relationship. This is indicated from the table of statistical test results for the relationship between variables. Positive in the strong category, the relationship between the concept of Karma Yoga and employee performance of 0.765 has a positive relationship in the strong category. The relationship between 
spiritual intelligence and employee performance has a positive relationship in the strong category and the results also show that the value of T statistics $>1.96$ or $\mathrm{p}$ value is significant $<0.05$. which means that the relationship has a positive and significant relationship.

\section{Discussion \\ The Relationship between the Concept of Karma Yoga and Spiritual Intelligence}

The concept of Karma Yoga is an effort or action (work) that is sincere, selfless, emphasizing work as a form of devotion and devotion to God (Niskama Karma). The test results show that the concept of Karma Yoga has a positive and significant relationship with spiritual intelligence. The concept of Karma Yoga is applied in LPD business activities in Buleleng Regency, including the sincerity that underlies the LPD in building its internal business processes through maximum operational activities and good customer management. sincerity in business processes certainly provides satisfaction to customers, which will realize the LPD's financial targets and encourage the achievement of company goals. The implementation of the concept of Karma Yoga can encourage the courage of LPD administrators to make better decisions and choose more effective funding sources. The same thing was also conveyed by PHDI (2013) if Dharma is used as a foundation in business, then the company's performance will increase.

Moreover, businesses/businesses that are built with the main objective of prospering the Balinese people or the local villager (Krama Desa) such as the Village Credit Institution (LPD), of course, the Karma Yoga Concept can be the key to success in its business strategy. Donaldson and Davis also describe stewardship theory as a new perspective in managing a business that emphasizes serving attitudes in line with the concept of Karma Yoga. The application of this concept will encourage the LPD management to think and act to always maintain and be oriented towards long-term organizational goals

\section{Relationship of Karma Yoga to Employee Performance}

The concept of Karma is a local Balinese culture in the form of sincere acts of the Balinese people. The application of the concept of Karma Yoga in a person is expected to be able to improve the performance of human resources. The results of hypothesis testing show that the concept of Karma Yoga in LPD employees has an effect and has a positive relationship with employee performance. With the positive influence and relationship, it will be able to improve the performance of LPD employees in Buleleng district, positively. This is in line with Ngurah et al. in Sugata (2018) saying that the teachings of Karma Yoga are a work ethic or work culture for Hindus in an effort to realize physical and spiritual prosperity and happiness. Karma Yoga accepts life's struggles and wants to succeed in those struggles. Besides that, it is not solely based on biological life but also concerns moral and spiritual life that can improve employee performance

\section{The Relationship of Spiritual Intelligence to Employee Performance}

The results showed that spiritual intelligence has a positive influence and relationship with employee performance. A positive relationship has a unidirectional relationship so that positive spiritual intelligence will result in 
positive employee performance; in other words, increased performance. The results of this study are in line with the results of previous research conducted by Lisda (2012), concluding that spiritual intelligence has a significant influence. Significant to employee performance, meaning that spiritual intelligence can increase employee performance.

\section{CONCLUSION}

Based on the formulation of the problem, objectives, theoretical basis, hypotheses and the results of the tests carried out, it can be concluded that the concept of Karma Yoga has a positive and significant relationship to Spiritual Intelligence and employee performance. Spiritual intelligence also has a positive and significant relationship to employee performance. employees of LPD who apply the concept of Karma Yoga in their business processes provide a positive and significant relationship to spiritual intelligence so that they can improve their performance; by increasing the employee performance, the LPD will provide better service, so that the Village Credit Institution (LPD) can maintain consistency and clarity. Village Credit Institutions (LPD) to be able to compete with other microfinance institutions.

\section{REFERENCES}

Koentjaraningrat. (2003). Pengantar Antropologi. Rineka Cipta.

Lisda, R. (2012). Pengaruh Kecerdasan Intelektual , Kecerdasan Emosi dan Kecerdasan Spiritual Terhadap Kinerja Karyawan. Majalah Ilmiah Informatika, 3(1).

Sugata, I. M. (2018). Tamblang Waluh : Transformasi Ajaran Karma Marga Yoga Dalam Tradisi Lokal bali Timur. Yoga Dan Kesehatan Volume, 1(1).

Wibowo, C. T. (2015). Analisis Pengaruh Kecerdasan Emosional (EQ) Dan Kecerdasan Spritual (SQ) Pada Kinerja Karyawan. Jurnal Bisnis \& Manajemen, 15(1), 1-16. 